\title{
Barna fra forsterket helsestasjon klarer seg bra
}

\author{
Barn av rusmisbrukere som har benyttet forsterket helsestasjon skårer \\ innenfor normalgrensene på kognitive tester, men har mer atferds- \\ problemer enn barn fra «vanlige» familier.
}

I 1994 ble det opprettet forsterket helsestasjon i Kristiansand - et lavterskeltilbud for gravide rusmisbrukere og deres barn opp til fire års alder. I perioden 1994-2002 hadde 102 gravide kontakt med helsestasjonen. Bjørg Hjerkinn har vært interessert $\mathrm{i}$ å undersøke hvordan det har gått med barna deres.

- Vi har fått utført nevropsykologiske undersøkelser av 40 av barna da de var i alderen 4-11 år, og en kontrollgruppe på 80 barn fra familier uten rusproblemer. Barna ble testet på ulike kognitive funksjoner, delt i fem ulike testområder, sier Hjerkinn. - De fleste kvinnene greide å kutte ut eller redusere rusmisbruket betraktelig i løpet av svangerskapet. Resultatene for barna fra forsterket helsestasjon ble gruppert på basis av om mødrene greide å kutte ut rusmisbruket i løpet av første trimester, eller ruste seg noe utover i svangerskapet.

Ingen av barna fra forsterket helsestasjon falt utenfor normalgrensene. Barn av mødre som hadde greid å slutte med rusmisbruk skåret signifikant dårligere enn kontrollgruppen på tre av fem testområder. Disse barna hadde stort sett vokst opp hos sine biologiske mødre, sier Hjerkinn.

- Alle bortsett fra ett av barna i den andre gruppen var eller hadde vært i fosterhjem. Denne gruppen hadde bedre testresultater enn de som hadde vokst opp med sine biologiske mødre, og skåret signifikant dårligere enn kontrollgruppen bare på eksekutive funksjoner, sier hun. Barna av mødrene med rusproblemer hadde mer atferdsproblemer enn barn i kontrollgruppen. De som vokste opp hos sine biologiske mødre trengte mer ekstraundervisning i skolen enn barn fra vanlige familier.

\section{Anne Forus}

anne.forus@hotmail.com

Tidsskriftet

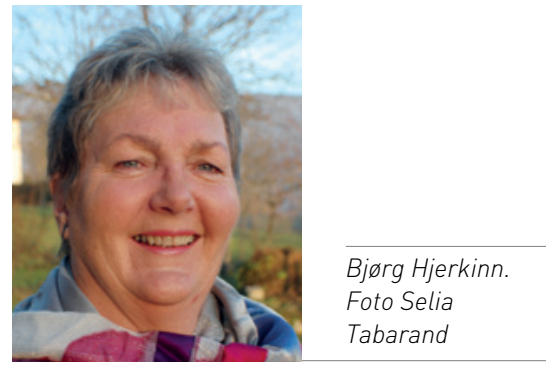

\section{Disputas}

Bjørg Hjerkinn disputerte for ph.d.-graden ved Universitetet i Oslo 13.1. 2012 med avhandlingen $A$ cohort study of pregnant substanceabusing women and their children, attending a Special Child Welfare Clinic in Kristiansand, Norway, 1994-2002.

\section{Riktig beregning av fødselstermin}

\author{
Den populasjonsbaserte metoden eSnurra beregner termin mer \\ nøyaktig enn eldre metoder.
}

Sikker fastsettelse av fødselstermin er et av spørsmålene rutineundersøkelsen rundt svangerskapsuke 17-19 skal gi svar på, og det er viktig at metodene som brukes ikke gir systematiske feil. Inger Økland som er overlege ved Kvinneklinikken, Stavanger universitetssjukehus, har undersøkt tre modeller for terminbestemmelse som brukes i kombinasjon med ultralydundersøkelse i sin doktoravhandling.

Økland og medarbeidere har i tre studier sett på målinger fra til sammen 73400 ultralydundersøkelser utført i Trondheim, Stavanger og i Oppland. De beregnet antatt fødselstermin med de to tradisjonelle metodene Snurra og Terminhjulet, og i to av studiene har de i tillegg brukt den nyere metoden eSnurra. Beregnet termin med de tre ulike metodene ble sammenliknet med faktisk fødselstidspunkt.

- Resultatene viste at de to tradisjonelle modellene, Snurra og Terminhjulet, ga systematiske avvik i terminberegningen. Avvikene var på 0-4 dager og varierte med fosterstør- relsen på undersøkelsestidspunktet. Snurra beregnet gjennomgående termin for sent, mens Terminhjulet beregnet termin for tidlig. eSnurra derimot, predikerte stabile, korrekte ultralydterminer, uavhengig av fosterstørrelsen ved undersøkelsen, og avviket mellom fødselstidspunkt og ultralydtermin var stort sett mindre enn ett døgn.

Diskusjonen om de overtidige har vært aktuell i mange år, men det blir paradoksalt å diskutere hvilken dag etter termin vi skal velge for kontroll eller induksjon så lenge ulike metoder fastsetter terminen til forskjellige dager. $\AA$ fastsette ultralydtermin for tidlig resulterer $\mathrm{i}$ at flere må kontrolleres og induseres unødvendig, noe som øker risikoen for kvinnene og belastningen på fødeavdelingene. Vi mener det nå er dokumentert at eSnurra er den beste metoden for terminbestemmelse i Norge, sier Økland.

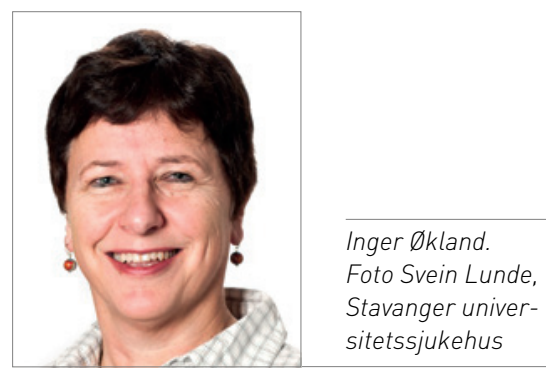

Disputas

Inger $\emptyset$ kland disputerte for dr.philos.-graden ved Norges teknisk-naturvitenskapelige universitet 13.1. 2012. Tittelen på avhandlingen er Biases in second-trimester ultrasound dating related to prediction models and fetal measurements. 